\title{
Hematological and biochemical profile of captive brown-throated sloths Bradypus variegatus, Schinz 1825, feeding on ambay pumpwood Cecropia pachystachya Trécul 1847
}

[Perfil hematológico e bioquímico da preguiça-de-garganta-marrom Bradypus variegatus, Schinz 1825, em cativeiro alimentando-se de embaúba Cecropia pachystachya Trécul 1847]

\author{
M.C. $T s c h a^{1}$, G.P. Andrade $e^{2}$, P.V. Albuquerque $e^{2}$, A.R. Tschá3, G.S. Dimech ${ }^{3}$, \\ C.J.F.L. Silva1, E.T.N. Farias ${ }^{3}$, M.J.A.A.L. Amorim² \\ 19Aluno de pós-graduação - Universidade Federal Rural de Pernambuco - Recife, PE \\ ${ }^{2}$ Universidade Federal Rural de Pernambuco - Recife, PE \\ ${ }^{3}$ Centro Universitário - Facol -UNIFACOL Vitória de Santo Antão, PE
}

\begin{abstract}
The aim of this study was to establish reference parameters for the hematological and biochemical levels of five healthy captive sloths of the species Bradypus variegatus (brown-throated sloth) feeding on Cecropia pachystachya (Ambay pumpwood), alternating with a period of free diet in the Dois Irmãos State Park (DISP) Recife, Pernambuco - Brazil.
\end{abstract}

Keywords: tests, hematology, biochemistry, ambay pumpwood, sloths

\section{RESUMO}

O objetivo da presente pesquisa foi estabelecer parâmetros de referência para níveis hematológicos e bioquímicos, de cinco preguiças sadias, da espécie Bradypus variegatus (preguiça-de-garganta-marrom), em cativeiro, alimentando-se de Cecropia pachystachya (embaúba) em períodos alternados com dieta livre, no Parque Estadual de Dois Irmãos (PEDI) Recife, Pernambuco-Brasil.

Palavras-chave: exames, hematologia, bioquímica, embaúba, bicho-preguiça

\section{INTRODUCTION}

Sloths, like anteaters, belong to the order Pilosa (Rezende et al., 2013). Sloths are represented by two genera which differ in many of their characteristics, both internal and external. The number of toes on the thoracic members are the most commonly used feature for distinguishing between the genus Choloepus (Illiger, 1811) which have two toes and belong to the Megalonychidae family and the genus Bradypus, comprised of four species Bradypus variegatus (Schinz 1825), the brown-throated sloth, Bradypus tridactylus (Linnaeus, 1758), the yellow-throated sloth, Bradypus torquatus (Illiger, 1811), the maned sloth and Bradypus pygmaeus (Anderson and Handley, 2001), the pygmy three-toed sloth.

The conservation status of the species Bradypus variegatus is classified by the IUCN

Recebido em 27 de janeiro de 2021

Aceito em 22 de abril de 2021

E-mail: mctscha@hotmail.com
(International Union for Conservation of Nature) as being of low concern (LC). This species has an ample distribution in the Neotropical region, occurring in both Central (Honduras, Nicaragua, Costa Rica and Panama) and South America (Peru, Bolivia, Argentina, Colombia, Ecuador, Venezuela and Brazil) (Wetzel, 1985; Moraes Barros et al., 2014; Miranda et al., 2015). In terms of their feeding habits, sloths are arboreal, herbivorous, non-ruminant, folivores, preferring young leaves, as well as feeding on the branches, shoots and buds of several vegetal species (Urbani and Bosque, 2007; Chiarello 2008). Leaves represent approximately $94 \%$ of the food consumed by sloths, followed by shoots (Queiroz, 1995). Sloths have a very selective diet, preferring fibrous leaves with low concentrations of soluble carbohydrates (Cáuper et al., 2006; Braz, 2018).

When studying the feeding habits of Bradypus variegatus in the Fatima Agroecological 
Scientific Station in Ecuador, Carrilo-Bilbao et al., (2016) observed that sloths consumed 14 plant species distributed across 10 genera and 10 families, with the family Urticaceae being the most frequently consumed. The feeding habits of these animals can have important implications in terms of their ability to digest cellulose, an abundant polysaccharide which comprises the main parts of plant cell walls, as well as secondary compounds that can be toxic even when consumed in small quantities (Cork and Foley, 1991). Chiarello (1998) considered two important aspects regarding nutrition and the selective characteristics attributed to sloths. Young leaves, which are preferred by these animals, have lower proportions of components that are difficult to digest such as, cellulose, tannins, alkaloids and lignin and have higher concentrations of sugars, water and proteins compared to mature leaves.

Montgomery and Sunquist, (1975); Nagy and Montgomery, (1980); Macnab, (1985); Gilmore et al. (2000), corroborated the fact that this leafbased diet contributes to a slow metabolism and low body temperature, resulting in sloths having slow movements and long periods of inactivity. For Cork and Foley (1991) the fact that sloths have a slow metabolism implies a reduction in the absorption of toxic plant substances, which may represent an adaptation to their folivorous habit. Belovsky and Schmitz (1994) affirmed that when sloths are in the wild, they avoid toxins through their selection of plant species and parts rich in nutrients, minerals and proteins such as, fruits, seeds, flowers, young leaves and shoots, which may not occur in captive conditions. This study involved the use of animals in captive conditions. Galvão et al. (2019), Garcia-Navarro, (2005) and Reis et al. (2008) highlighted that hematological analyses of captive animals in captive conditions are predisposed to several pathologies, therefore, it is necessary to perform laboratory tests including serum hematology and biochemistry tests, in order to diagnose, prevent, guide treatments and accompany the health of these animals.

Studies that evaluate the hemograms of sloth species are scarce thus it is of great importance that databases are expanded to include populations of wild animals, especially those that live in urban fragments (Queiroz et al., 2015). From Gilmore et al. (2000) to Goffart (1971), who summarized information on sloth blood biochemistry, few studies evaluating the blood parameters of these animals exist, with the majority of these studies focusing on the species Choloepus hoffmani, for example Wallace and Oppenheim, (1996) and also on Choloepus didactylus for example Vogel et al. (1999), who provided detailed data on the blood parameters of sloths of the genus Choloepus spp. in captivity. Xavier (2006) affirmed that sloths of the genus Bradypus have difficulty in adapting to captivity, presenting high fragility.

Scientific studies that deal with the hematological and biochemical parameters of wild fauna are rare, however, more research is needed to understand the singularities of these animals (Galvão et al., 2019). According to Queiroz et al. (2015) hematological studies of sloth species are very rare, thus it is of great importance that databases expand to include populations of wild animals, especially those than inhabit urban fragments (Queiroz et al., 2015). This study was performed with the aim of evaluating the serum biochemistry and hematological patterns found in Bradypus variegatus feeding on Ambay pumpwood, Cecropia pachistacya, in captivity.

\section{METHODS AND MATERIALS}

The collection site for this study was carried out in the Dois Irmãos State Park (DISP), Recife/Pernambuco - Brazil, with the coordinates $7^{\circ} 59^{\prime} 30^{\prime}$ e $8^{\circ} 01^{\prime} 00^{\prime \prime} \mathrm{S}$ e $30^{\prime \prime} \mathrm{S}$ e $34^{\circ} 52^{\prime} 30^{\prime \prime}$. 34 $57^{\circ} 30^{\prime \prime} \mathrm{W}$. The DISP is comprised of a low land ombrophiles forest remnant (Veloso et al., 1991), where the zoological botanical gardens cover an area of 384.42 ha (Weber and Rezende, 1998), of which 14 hectares belong to the zoo. Animals and management five clinically healthy animals from the Dois Irmãos zoo were used in this study, two males and three females. Of the five study animals four were juveniles and one was an adult, with their respective weights provided in the Table 1. The samples were collected during the period from August and December 2019. 
Hematological and biochemical...

Table 1. Data generated for the group of five Bradypus. variegatus sloths

\begin{tabular}{lccc}
\hline Dentification & Sex & Age & Weight (grams) \\
\hline Sloth 1 & Male & Juvenile & 2.84 \\
Sloth 2 & Female & Juvenile & 2.15 \\
Sloth 3 & Male & Juvenile & 3.02 \\
Sloth 4 & Female & Adult & 4.11 \\
Sloth 5 & Female & Juvenile & 2.68 \\
\hline
\end{tabular}

During a period of 14 days, the animals were exclusively fed Cecropia pachystachya, with the aim of adapting the animals to this diet and eliminating any remaining gastrointestinal content. The first phase of the experiment (P1) included the period between days 15 and 36, after the dietary adaptation phase, totaling 21 days. After this period, the animals were submitted to a free diet for 14 days, which formed the second experimental phase (P2) and included the period between days 15 and 36 after the free diet adaptation phase, also totaling 21 days. Collection and processing of samples all the procedures were approved by the Ethics Commission for the Use of Animals at the Federal Rural University of Pernambuco (CEUA-UFRPE) under the reference number 100-2109, the Heritage Management and Traditional Knowledge Association (SISGEN) under the reference number A515AC6 and the System of Authorization and Biodiversity Information (SISBIO) under the reference number 46665-9.

For the collection of blood samples, the animals were manually restrained with no sedation. The collection period lasted approximately between 15-20 minutes. The blood samples were collected through cephalic venipuncture, using $3 \mathrm{ml}$ syringes and disposable needles (20 x 0.55). The blood samples were collected in two types of tubes. One dry tube, for the collection of serum and the biochemical analysis and another tube containing EDTA (ethylenediaminetetraacetic acid), for the hemogram. The hematological and biochemical analyses were performed in the Department of Quality of Life (DQV) at the Federal Rural University of Pernambuco -
UFRPE. The hemogram was performed using the equipment model Mindray 300 da Roche, using the kit from the same manufacturer as a diluting reagent, following the manufacturer's instructions. Manual observation under a microscope was also performed. The biochemical analysis was carried out using a cobas ${ }^{\circledR}$ c 111 da Roche spectrophotometer.

\section{RESULTS}

Tables 2 and 3 respectively present the results of the hematological and biochemical serum analysis of the sloth species Bradypus variegatus. Due to the limitation of (n) in this study, the results were not analyzed based on sex. For the hematology (Table 2), erythrocytes, hematocrit and hemoglobin presented statistical differences and the indices for Phase 2 were higher for both variables when compared with Phase 1. For platelets, a higher level was found in Phase 2 than was observed in Phase 1.

When observing the biochemical serum levels (Table 3), it is possible to note that the liver function enzymes ALT and GGT were lower in Phase 1 when compared to Phase 2 however, the opposite was found for AST, where its levels were higher in Phase 1. Despite the statistical significance, it is possible to observe that the cholesterol indices and the HDL fraction tended to be higher for animals during Phase 1 compared to Phase 2, which may be correlated with the higher level of triglycerides in Phase 1. Together with the liver function, kidney function was also significantly different between the phases. Urea and creatin presented lower values in Phase 1. 
Table 2. Results of the hematological values of Bradypus variegatus, analysed using a paired T-test with the application of the Kolmogorov-Smirnov test of normality

\begin{tabular}{lcc}
\hline \multicolumn{1}{c}{ Hematological Biomarkers } & Phase 1 & Phase 2 \\
\hline Erythrocytes x $10^{6} \mu^{*}$ & $3.01 \pm 0.10$ & $3.41 \pm 0.28$ \\
Hematocrit \%* & $10.88 \pm 0.50$ & $12.82 \pm 1.57$ \\
Hemoglobin g/dl* & $31.88 \pm 1.41$ & $36.16 \pm 4.10$ \\
MCV (fL) & $86.10 \pm 41.69$ & $105.80 \pm 3.70$ \\
MCHC g/dl* & $34.12 \pm 0.11$ & $35.42 \pm 0.74$ \\
RDW \% & $18.04 \pm 0.57$ & $17.58 \pm 0.50$ \\
Leukocytes x $10^{3} \mu$ & $16.06 \pm 4.03$ & $14.88 \pm 5.3$ \\
Rod neutrophils\% & $0.20 \pm 0.45$ & $0.20 \pm 0.45$ \\
Segmented neutrophils & $15.80 \pm 12.38$ & $13.60 \pm 6.19$ \\
Basophils\% & $0.00 \pm 0.00$ & $0.00 \pm 0.00$ \\
Eosinophils\% & $2.60 \pm 0.55$ & $2.40 \pm 0.55$ \\
Lymphocytes \% & $72.80 \pm 16.04$ & $75.20 \pm 10.45$ \\
Monocytes \% & $8.60 \pm 3.71$ & $8.60 \pm 4.34$ \\
Platelets $x 10{ }^{*}$ & $72.2 \pm 25.12$ & $136.6 \pm 27.64$ \\
\hline
\end{tabular}

Phase 1: group fed with Cecropia pachystachya, Phase 2: mixed food group; MCV: mean corpuscular volume; MCHC: mean corpuscular hemoglobin concentration; RDW: range of red blood cell distribution.

Table 3. Results of serum biochemistry values for Bradypus variegatus, analyzed using a paired T-test with the application of a Kolmogorov-Smirnov test of normality

\begin{tabular}{lcc}
\multicolumn{1}{c}{ Serum Biochemistry } & Phase 1 & Phase 2 \\
\hline ALT U/L* & $3.08 \pm 0.69$ & $3.53 \pm 0.89$ \\
AST U/L* & $267.40 \pm 26.44$ & $225.58 \pm 28.89$ \\
GGT U/L* & $12.53 \pm 2.87$ & $15.35 \pm 1.37$ \\
Total bilirubin mg/dl & $0.03 \pm 0.05$ & $0.03 \pm 0.05$ \\
Direct bilirubin mg/dl & $0.00 \pm 0.00$ & $0.05 \pm 0.06$ \\
Triglycerides mg/dl* & $81.85 \pm 21.46$ & $48.97 \pm 24.62$ \\
Total cholesterol mg/dl & $123.06 \pm 12.36$ & $86.40 \pm 52.90$ \\
HDL cholesterol mg/dl & $61.12 \pm 17.10$ & $59.76 \pm 28.23$ \\
Glucose mg/dl & $70.24 \pm 8.84$ & $57.55 \pm 18.08$ \\
Urea mg/dl* & $35.99 \pm 8.38$ & $43.98 \pm 3.06$ \\
Creatin mg/dl* & $0.15 \pm 0.06$ & $0.35 \pm 0.06$ \\
Uric acid mg/dl & $1.73 \pm 0.21$ & $1.90 \pm 0.34$ \\
Albumin g/dl & $31.09 \pm 2.45$ & $32.12 \pm 1.76$ \\
\hline
\end{tabular}

Different letters in the same line indicate $\mathrm{P}<0.05$. Phase 1: group fed with Cecropia pachystachya; Phase 2: mixed food group; ALT: alanine aminotransferase; AST: aspartate aminotransferase; GGT: $\mathbb{p}$-glutamyltransferase.

\section{DISCUSSION}

The nutritional requirements of wild animals are still poorly understood and data based on the nutritional requirements of domestic animals are frequently used with the aim of providing the adequate dietary elements for wild species. Montgomer and Suquist (1978) highlighted that when in the wild, sloths of the species Bradypus variegatus feed on a range of diverse vegetation, whereas in captive conditions they feed mainly on Ambay pumpwood (Cecropia pachystachya). During in loco observations, a dietary preference for $C$. pachystachya has been observed. The predilection for a specific component, for example, Cecropia pachystacya for sloths, leads to a large supply of this ingredient in captivity, as these animals prefer this food type when in the wild. However, in the wild, food provisions are diverse both in terms of the area the animal inhabits, as well as the edaphoclimatic characteristics of the region. Thus, providing Cecropia pachystachya ad libitum in sloth diets can cause an imbalance in the acquired nutritional components, which reflects changes in blood parameters, for example.

Sloths have been poorly studied, especially in terms of their blood hematology and biochemistry. In the literature available 
worldwide, greater attention has been paid to two-toed sloths, Choleopus spp., compared to studies on Bradypus spp., especially Bradypus variegatus. Galvão et al. (2019) affirmed that in captive conditions these animals are susceptible to more pathologies and thus, it is necessary to perform tests with the aim of evaluating the health of individuals. These pathologies can also be associated with inadequate nutrition, despite attempts to offer a diet similar to that available in the wild, it may not necessarily contain the ideal quantity and quality of nutrients for the organism, as observed by Dierenfeld (1997), who noted that wild fauna in captivity do not require specific foods, but rather specific nutrients.

Although literature on sloth blood references, especially for the species Bradypus variegatus, is rare, from the data obtained from healthy animals in different regions across the country, it was possible to establish correlations with the data collected in this study, where the influence of Cecropia pachystachya consumption on the serum hematology and biochemistry patterns of Bradypus variegatus individuals was evaluated. For the most part, wild fauna requires chemical containment for the collection of biological samples (Pereira et al., 2020). In this study the animals were contained without the use of sedatives, which allowed for a more reliable assessment of the results, since the use of medication tends to promote the alteration of these parameters.

In terms of the hematological evaluation (Table. $1)$, it is possible to observe significant statistics $(\mathrm{P}<0.05)$ between phases for red blood cells, hemoglobin, hematocrit and MCHC. It is possible to note that for $\mathrm{P} 2$, the cited parameters were more elevated compared to P1. This may be associated with diet, since nutritional aspects are limiting factors for the production and maturing of different blood cells. A more diverse diet, as presented in P2, may have influenced the increase observed for these variables, potentially as a result of a better supply of proteins, lipids and carbohydrates which are essential for the production and maturing of blood cells and also hemoglobin production

Lower levels of hematocrit and higher levels of hemoglobin were observed when compared with the findings of Galvão et al. (2019), Pereira et al. (2020) and Queiroz et al. (2015). When associating these findings with the observed values of MCV and RDW it is possible to infer that the observed aspects for hematocrit and hemoglobin may have nutritional characteristics, since normal levels of MCV with increased RDW data are indicative of a nutritional disorder. Although presenting significant statistics between phases, the MCHC was found to be within the observed limits by the authors previously cited. As Queiroz et al. (2015) also observed, the absence of a reference profile increases the difficulty of individual evaluation, which should be associated with other evidence to indicate the health status of each animal.

Furthermore, Queiroz et al. (2015) demonstrated that most of the hematological parameters evaluated did not differ notably between populations, nor when evaluating the effect of sex on these parameters. However, the mean value of platelets for females was considerably higher than for males. In this study, the platelet parameters demonstrated the greatest variation in mean between the phases, which is similar to the results found in the literature. Likewise, Galvão et al. (2019) observed that females tended to have a greater number of platelets when compared to males. The total variation in mean platelet number found in the different studies may correlate with the number of females present in each group. Furthermore, the higher levels of this parameter in our study may be due to the fact that a greater proportion of evaluated animals were females $(n=3)$. No explanation for the difference in platelet number between males and females was observed in this study.

Considering white cells, there was no observed statistical difference between the phases. However, the results of this study were similar to those observed by Galvão et al. (2019) for the total count of leukocytes and were markedly higher than the results demonstrated by Pereira $e t$ al. (2020) and Queiroz et al. (2015) for the same variable. Such characteristics may be associated with individual aspects of each animal, as well as with the environmental conditions to which each group is exposed. The striking neutrophilia values, which are important when observing the increase in the total number of leukocytes, can be associated with the stress of capture due to restraining the animals for the collection of samples. This type of alteration has already been described for different wild species, for example 
Rhesus macaques (Morrow-Tesch et al., 1993), common squirrel monkeys (Coe and Hall, 1996) and the common marmosets (Cunha et al., 2005).

Data on the blood biochemistry of the species Bradypus variegatus are rarely observed and when analyzing these data, the results include only a selection of parameters, as demonstrated by Pereira et al. (2020) who only evaluated the liver and kidney profiles of sloths. When animals inhabit urban or wild areas but occupy restricted spaces, competition for food resources is promoted, especially where there is a scarcity of young leaves, as this results in a greater ingestion of mature leaves, which consequently elevates the indices of toxic components and overloads the liver (Pereira et al., 2020). The chemical composition of Cecropia pachystacya, according to Costa and Hoscheid (2018) contain saponins, which are metabolites that have direct liver action, and which can be correlated to findings for ALT, AST and GGT. When compared with the liver profile observed by Pereira et al. (2020), the ALT levels in this study were lower, whereas the AST levels remained similar to the levels previously observed by the cited author.

Correlating the findings of Wallace and Oppenheim, (1996) for Choleopus hoffmanni, the ALT data were similar to the findings of this study, whereas for AST the indices were greater. The discrepancy between the data may be due to the dietary elements provided in the different studies, even if the diets provided in the two studies were equivalent, where all the animals received Cecropia pachystachya, the origin and age of the leaves can present different concentrations for different compounds, which may or may not result in liver overload causing a fluctuation in ALT and AST data. GGT levels, another liver enzyme, were higher in this study compared to results observed by Wallace and Oppenheim, (1996) and Vogel et al. (1999), which may also be correlated to diet characteristics that influence liver activity.

In a phytochemical analysis by Costa and Hoscheid (2018), Cecropia pachystacya presented important levels of reduced sugars and carbohydrates, which may justify the increase in triglycerides observed in Phase 1 of this study, where the sloth diet was exclusively comprised of this plant species. Comparing these findings with Wallace and Oppenheim, (1996), it is possible to infer that diet can influence the lipid profile of these animals, since the triglyceride levels and cholesterol varied considerably between the studies. The results for cholesterol and HDL fraction between the phases reinforce the influence of Cecropia pachystacya components on the lipid profile of Bradypus variegatus. Whereas in terms of kidney function, the levels of urea and creatin were higher in Phase 2, the urea levels may be correlated to protein diet indices, since this metabolite was noticeably higher and reflects the excretion of protein. Pereira et al. (2020) observed similar data for urea in Bradypus variegatus, however, the creatin levels found in this study were lower than observed by the authors. The creatin data were also lower than those described by Wallace and Oppenheim, (1996) and Vogel et al. (1999), who also observed lower urea values in Choloepus hoffmani. Creatin is not strongly influenced by diet but it can be correlated to levels of kidney damage and skeletal muscle metabolism. A better understanding of these parameters is obtained through the chemical assessment of urine.

We observed, in loco, the preference of Cecropia pachystachya, despite being offered among other plants such as, jackfruit leaves, sucupira, poppy (flowers), banana (fruit) among others. This observation corroborates the observations of Montgomery and Sunquist (1978), who highlighted that these animals, when in the wild, feed on a variety of vegetation but when in captivity feed mainly on Cecropia pachysachya. Hematological and biochemical data for wild animals are scarce and difficult to correlate as there are important differences in nutrition, environment and management, in addition to the difficulty in the collection and processing of samples. Studies on small populations provide initial data for the study of pathophysiological aspects of different species. It is important to note that in all populational analyses there are natural variations between individuals, as well as characteristics specific to sex and age, which often cannot be analyzed due to the low number of individuals evaluated. 


\section{CONCLUSION}

The sloth presents unique metabolic characteristics, and the literature is in need of hematological and biochemical serum data, especially for the species Bradypus variegatus. The collection of these data allows for the evaluation of the influence of diet on blood parameters which are important bioindicators for the physiopathological state of the animal.

\section{ACKNOWLEDGEMENT}

This study was financed in part by the Coordenação de Aperfeiçoamento de Pessoal de Nível Superior - Brasil (CAPES) - Finance Code 001.

\section{REFERENCES}

ANDERSON, R.P.; HANDLEY JÚNIOR, C.O. A new species of three-toed sloth (Mammalia: Xenarthra) from Panamá, with a review of the genus Bradypus. Proc. Biol. Soc., v.114, p.1-33, 2001.

BELOVSKY, G.E.; SCHMITZ, O.J. Plant defenses and optimal foraging by mammalian herbivores. J. Mammal., v.75, p.816-832, 1994.

BRAZ, R.S. Aspectos morfológicos externos macroscópicos, ecometria e tonometria de rebote do bulbo do olho em bicho-preguiça (Bradypus variegatus, Schinz. 1825). 2018. 73f. Dissertação (Mestrado) - Pós-Graduação em Ciência Anima Tropical, Universidade Federal Rural de Pernambuco, PE.

CARRILlO-BILBAO, G.V. et al. Área de vida, dieta, preferencia de estrato vertical y uso del tiempo de Bradypus variegatus, liberados en la Estación Científica Agroecológica Fátima. Rev. Bionatura, v.1, p.118-122, 2016.

CÁUPER, G.C.B.; CÁUPER, F.R.M.; BRITO, L.L. Biodiversidade Amazônica: flora amazônica. Manaus: Centro Cultural dos Povos da Amazônia, 2006.

CHIARELLO, A.G. Diet of the Atlantic forest maned sloth Bradypus torquatus (Xenarthra: Bradypodidae). J. Zool., n.246, p.11-19, 1998.

CHIARELLO, A.G. Sloth ecology: an overview of feld studies. In: VIZCAÍNO, S.F.; LOUGHRY, W.J. (Eds.). The Biology of the Xenarthra. Florida: University Press of Florida. 2008. p.269-280.
COE, C.L.; HALL, N.R. Psychological disturbance alters thymic and adrenal hormone secretion in parallel but independent manner. Psychoneuroendocrinology, v.21, p.237-247, 1996.

CORK, S.J.; FOLEY, W.J. Digestive and meTableolic strategies of arboreal mammalian folivores in relation to chemical defenses in temperate and tropical forests. In: PALO, R.T.; ROBBINS, C.T. (Eds.) Plant defenses against mammalian herbivory. Flórida: CRC Press, 1991. 200p.

COSTA, J.C.F.; HOSCHEID, J. Perfil fitoquímico e avaliação da atividade antimicrobiana de extrato aquoso e etanólico de folhas de Cecropia pachystachya. Rev. Fitos, v.12, p.175-185, 2018.

CUNHA, M.S.; LOPES, D.R.; SOUSA, M.B.C. Variação na contagem de leucócitos em Callithrix jacchus (Linnaeus, 1758) submetidos a uma situação de estresse agudo. Rev. Bras. Zoocienc., v.7, p.217-229, 2005.

DIERENFELD, E. Captive wild animal nutrition: a historical perspective. Proc. Nutrit. Soc., v.56, p.989-999, 1997.

GALVÃO, G.R.; GIESE, E.G.; GALVÃO, G.R. et al. Hematological values in bradypus variegatus (Schinz, 1825) from creatories of the Belém metropolitan region. Rev. Ibero-Am. Ciênc. Amb., v.10, p.82-88, 2019.

GARCIA-NAVARRO, C.E.K. Manual de hematologia veterinária. 2.ed. São Paulo: Varela, 2005.

GILMORE, D.P.; COSTA, C.P.; DUARTE, D.P.F. Sloth biology: an update on their physiological ecology, behavior and role as vectors of arthropods and arboviruses. Braz. J. Med. Biol. Res., v.34, p.9-25, 2000.

GOFFART, M. Function and form in the sloth. Oxford: Pergamon Press, 1971. 225p.

MACNAB, B.F. Energetics, population biology and distribuition of Xenarthrans, living and extinct. In: MONTGOMERY, G.G. (Ed.). The Evolution and ecology of armadillos sloths and vermilinguas. Washington: Smithsonian Institution Press, 1985. 
MIRANDA, M.S.; FONTENELLE, J.H.; PECORA, I.L. Population structure of a native and an alien species of snail in an urban fragment of Atlantic Rainforest. J. Nat. Hist., n.49, p.1935, 2015.

MONTGOMERY, G.G.; SUNQUIST, M.E. Habitat Selection and Use by two-toed and three toed sloths. In: MONTGOMERY, G.G. (Ed.). The ecology of arboreal folivores. Washington: Smithsonian Institution Press, 1978.

MONTGOMERY, G.G.; SUNQUIST, M.E. Impact of sloths on neotropical energy flow and nutrient cycling. In: GOLLEY, F.; MEDINA, E. (Eds.). Tropical ecological systems: trends in terrestrial and aquatic research. New York: Springer-Verlag, 1975.

MORAES-BARROS, N.; CHIARELLO, A.; PLESE, T. Bradypus variegatus. The IUCN Red List of Threatened Species, 2014. e.T3038A47437046. Available in: https://dx.doi.org/10.2305/IUCN.UK.20141.RLT S.T3038A47437046.en. Accessed in: 6 Jan. 2021.

MORROW-TESCH， J.L.; McGLONE， J.J.; NORMAN, R.L. Consequences of restraint stress on natural killer activity, behavior, and hormone levels in rhesus macaques (Macaca mulatta). Psychoneuroendocrinology, v.18, p.383-395, 1993.

NAGY, K.A.; MONTGOMERY, G.G. Field me Tableolic rate, water flux, and food consumption in three-toed sloths (Bradypus variegatus). J. Mammal., v.61, p.465-472, 1980.

PEREIRA, K.F.; SILVA, I.O.; SILVA, F.F.R. et al. Hematology and serum biochemistry of freerange brown-throated sloths in two urban areas in Brazil. Vet. World, v.13, p.2033-2038, 2020.

QUEIROZ, C.; BOMFETI, C.A.; GONÇALVES, A.M.P.M. et al. Hematologia de preguiças de três dedos Bradypus variegatus (Bradypodidae, Xenarthra) da praça Tiradentes. Rev. Vozes Vales, v.4, p.1-11, 2015.

QUEIROZ, H.L. Preguiças e guaribas, os mamíferos folívoros arborícolas do Mamirauá. Brasília: $\mathrm{CNPq}$ e Sociedade Civil Mamirauá, 1995. 160p.
REIS, A.C.G.; SANTANA, A.M.; FAGLIARI, J.J. et al. Hematologia e bioquímica serica de pacas (Agouti paca, Linnaeus, 1766) criadas em cativeiro. In: CONFERÊNCIA SUL-AMERICANA DE MEDICINA VETERINÁRIA, 8., .2008; Rio de Janeiro. Anais... Rio de Janeiro: CRMV e ANCLIVEPA, 2008.

REZENDE, L.C.; GALDOS-RIVEROS, A.C.; MIGLINO, M.A. et al. Aspectos da biologia reprodutiva em preguiça e tamanduá: uma revisão. Rev. Bras. Reprod. Anim., v.37, p.354359, 2013.

URBANI, B.; BOSQUE, C. Feeding ecology and postural behaviour of the three-toed sloth (Bradypus variegatus flaccidus) in northern Venezuela. Mammal. Biol. Z. Säugetierkunde, v.72, p.321-329, 2007.

VELOSO, H.P.; RANGEL FILHO, A.L.R.R.; LIMA, J.C.A. Classificação da vegetação brasileira,adaptada a um sistema universal. Rio de Janeiro: IBGE, 1991.

VOGEL, I.; VIE, J.C.; DE THOISY, B. et al. Hematological and serum chemistry profiles of free-ranging southern two-toed sloths in French Guiana. J. Wildl. Dis., v.35, p.531-535, 1999.

WALLACE, C.; OPPENHEIM, Y.C. Hematology and serum chemistry profiles of captive Hoffmann's two-toed sloths (Choloepus hoffmanni). J. Zoo Wildl. Med., v.27, p.339-345, 1996.

WEBER, A.; REZENDE, S.M. Reserva ecológica e Parque Dois Irmãos: histórico e situação atual. In: MACHADO, I.C.; LOPES, A.V.: PÔRTO, K.C. (Orgs.). Reserva ecológica de Dois Irmãos: estudos em um remanescente de Mata Atlântica em área urbana (Recife Pernambuco - Brasil). Recife: UFPE, 1998.

WETZEL, R.M. The identification and distribution of recent Xenarthra (=Edentata). In: MONTGOMERY, G.G. The evolution and ecology of armadillos, sloths and vermilinguas. Washington: Smithisonian Institution Press, 1985.

XAVIER, G.A.A. Aspectos clínicos e de manejo de preguiça-de-garganta - marron Bradypus variegatus (Schinz, 1825) de vida livre na Mesorregião Metropolitana do Recife, Pernambuco, Brasil. 2006. 69f. Tese (Doutorado em Ciência Veterinária) - Universidade Federal Rural de Pernambuco, Recife, PE. 